\title{
ANALISIS FAKTOR-FAKTOR YANG MEMPENGARUHI NIAT KUNJUNGAN KEMBALI WISATAWAN PADA DAYA TARIK WISATA DI KABUPATEN BADUNG
}

\author{
Ni Nyoman Ayu Wiratini $\mathbf{M}^{1}$ \\ Nyoman Djinar Setiawina ${ }^{2}$ \\ Ni Nyoman Yuliarmi ${ }^{3}$
}

${ }^{1}$ Fakultas Ekonomi dan Bisnis Universitas Udayana (Unud), Bali, Indonesia

1email: nyomanayuwiratini@yahoo.com

${ }^{2}$ Fakultas Ekonomi dan Bisnis Universitas Udayana (Unud), Bali, Indonesia

${ }^{3}$ Fakultas Ekonomi dan Bisnis Universitas Udayana (Unud), Bali, Indonesia

\begin{abstract}
ABSTRAK
Tujuan penelitian ini adalah 1) Menganalisis pengaruh daya tarik wisata, fasilitas, dan kualitas pelayanan terhadap kepuasan wisatawan. 2) Menganalisis pengaruh daya tarik wisata, fasilitas, kualitas pelayanan dan kepuasan wisatawan terhadap niat kunjungan kembali wisatawan. 3) Menganalisis pengaruh tidak langsung kepuasan wisatawan yang memediasi daya tarik wisata, faslitas, dan kualitas pelayanan terhadap niat kunjungan kembali wisatawan. Metode pengumpulan data dengan observasi, wawancara mendalam serta wawancara terstruktur. Sumber data penelitian ini adalah data primer yang diperoleh dari penyebaran kuesioner pada 156 responden di 4 daya tarik wisata yang dikenakan retribusi, dan data sekunder. Alat analisis yang digunakan dalam penelitian ini adalah metode Path Analisys. Hasil Penelitian ini menunjukkan Daya Tarik Wisata, Kualitas Pelayanan dan Fasilitas berpengaruh positif dan signifikan terhadap Kepuasan Wisatawan.Daya Tarik Wisata dan Kepuasan Wisatawan berpengaruh Positif dan signifikan terhadap Niat Kunjungan Kembali Wisatawan. Kualitas Pelayanan dan Fasilitas berpengaruh positif namun tidak signifikan terhadap Niat Kunjungan Kembali Wisatawan, dan Variabel Kepuasan Wisatawan merupakan variabel yang memediasi pengaruh Daya Tarik Wisata, Kualitas Pelayanan, Fasilitas terhadap Niat Kunjungan Kembali Wisatawan..

Kata Kunci: Daya Tarik Wisata, Kualitas Pelayanan, Fasilitas, Kepuasan Wisatawan, Niat Kunjungan Kembali Wisatawan.
\end{abstract}

\begin{abstract}
The purpose of this study are 1) To analyze the influence of tourist attraction, facilities, and quality of service to the satisfaction of tourists. 2) Analyzing the influence of tourist attraction, facilities, service quality and satisfaction of tourists to the intention of returning tourists visit. 3) Analyzing the indirect influence of tourist satisfaction that mediates tourist attraction, facilities, and quality of service to the intention of returning tourists. Methods of data collection with observation, in-depth interviews and structured interviews. The data source of this research is primary data obtained from the spreading of questionnaires on 156 respondents in 4 tourist attraction which is subject to retribution, while secondary data, obtained from Badung Regency Revenue Service, Badung Regency Tourism Office, Central Bureau of Statistic (BPS) Badung Regency and Agency Central Statistics (BPS) of Bali Province. Analyzer used in this research is Path Analisys method. The results of this study indicate Attraction, Service Quality and Facilities have a positive and significant impact on Tourists Satisfaction. Tour Attractions and Travelers's Satisfaction Influence Positive and Significant to Tourist Visits Intention. Quality of Service and Facilities has a positive but insignificant effect on Tourist Visits Intention, and Tourists Satisfaction Variables is a variable that mediates the effect of Tourism Attraction, Service Quality, Facilities on Tourist Visits.
\end{abstract}

Keywords: Travel Attractions, Service Quality, Facilities, Tourists Satisfaction, Return Visits 
Ni Nyoman Ayu Wiratini M., N. Djinar Setiawan, dan Ni Ny. Yuliarmi. Analisis Faktor.....

\section{PENDAHULUAN}

Pembangunan sektor pariwisata di daerah dengan lebih mengkedepankan pembangunan pariwisata yang berkelanjutan, dengan melibatkan masyarakat dalam kegiatan kepariwisataan.Pemerintah dalam upayamengembangkan pariwisata yang berkelanjutan dan berwawasan lingkungan, perlu dilakukan upaya-upaya yang dapat menjaga keaslian, keindahan, keunikan daya tarik wisata sebagai salah satu potensi yang harus dijaga dan dipelihara sebagai bentuk penawaran kepada wisatawan terhadap kepariwisataan di Indonesia.Menurut AlAbabneh (2013) menyatakan bahwa kualitas pelayanan pada fasilitas, aksebilitas dan daya tarik wisata berdampak langsung pada kepuasan wisatawan, dimana hal ini berdampak terhadap tinggi atau rendahnya jumlah kunjungan wisatawan, sehingga niat kunjungan kembali wisatawan padadaya tarik wisata tersebut dipengaruhi oleh kesan yang didapat wisatawan dan kesan yang didapat merupakan wujud kepuasan wisatawan terhadap daya tarik wisata, fasilitas dan kualitas pelayananannya. Ulusoy (2011), yang menyatakan bahwa pendapatan pariwisata merupakan sumber penting bagi pertumbuhan ekonomi dan harus didukung fasilitas pariwisata. Kabupaten Badung merupakan salah satu tujuan wisata di Bali serta mempunyai daya tarik wisata yang potensial dan mampu menarik kunjungan wisatawan baik wisatawan mancanegara maupun domestik, namun belum optimal mampu menarik minat kunjungan wisatawan.

Sesuai dengan paradigma pembangunan pariwisata yang berkembang saat ini, yaitu pembangunan pariwisata berkelanjutan dan berwawasan lingkungan, yang mmengedepankan pariwisata yang mampu menarik kunjungan wisatawan tanpa mengesampingkan dampak terhadap lingkungan serta mampu memberikan 
kontribusi kepada masyarakat di sekitar daya tarik wisata.Pada perjanjian kerjasama disebutkan adanya sistem pendistribusian hasil retribusi tempat wisata antara pihak pertama (Pemerintah Kabupaten Badung) dan pihak kedua (Pengelola obyek daya tarik wisata yang dalam hal ini dikelola langsung oleh Desa Adat). Hal ini tentunya akan memotivasi pengelola untuk meningkatkan jumlah kunjungan wisatawan dengan melakukan upaya-upaya yang dapat menjaga keaslian, keindahan serta kelestarian lingkungannya, sehingga mampu menarik wisatawan untuk berkunjung. Mengingat niat kunjungan kembali wisatawan berpengaruh terhadap jumlah kunjungan wisatawan dari tahun ke tahun serta dampak dari jumlah kunjungan wisatawan terhadap terhadap kesejahteraan masyarakat serta pendapatan asli daerah Kabupaten Badung.

Berdasarkan latar belakang, maka tujuan penelitian ini adalah untuk menganalisis: 1) pengaruh daya tarik wisata, fasilitas, dan kualitas pelayanan terhadapkepuasan wisatawan. 2) pengaruhdaya tarik wisata, fasilitas, kualitas pelayanan dan kepuasan wisatawan terhadap niat kunjungan kembali wisatawan. 3) pengaruh tidak langsung kepuasan wisatawan yang memediasi daya tarik wisata, fasilitas, dan kualitas pelayanan terhadap niat kunjungan kembali wisatawan.

\section{METODE PENELITIAN}

\section{Lokasi Penelitian}

Lokasi Penelitian merupakan daya tarik wisata yang dikenakan retribusi tempat rekreasi di Kabupaten Badung, yaitu daya tarik wisata Uluwatu, Taman Ayun, Alas Pala Sangeh dan Air Terjun Nungnung. Sedangkan ruang lingkup 
Ni Nyoman Ayu Wiratini M., N. Djinar Setiawan, dan Ni Ny. Yuliarmi. Analisis Faktor.....

penelitian meliputi 4 daya tarik wisata yang dikenakan retribusi. Melihat adanya peningkatan jumlah kunjungan wisatawan di satu sisi dan terjadinya penurunan jumlah kunjungan wisatawan di sisi lain sebagai dampak dari adanya niat kunjungan kembali wisatawan pada keempat daya tarik wisata, sehingga perlu dilakukan penelitian untuk menganalisis faktor-faktor yang mempengaruhi niat kunjungan kembali wisatawan tersebut.

\section{Jenis Data menurut Sifat Data dan Sumber Data}

Jenis data yang digunakan adalah kualitatif dan kuantitatif, serta dari sumber sekunder dan primer. Data kualitatif dalam penelitian ini yang dinyatakan secara tertulis dan lisan yang berkaitan dengan penelitian, yaitu data mengenai uraian data. Data kuantitatif seperti data jumlah wisatawan berkunjung ke Kabupaten Badung yang merupakan data sekunder, sedangkan data kualitatif dari sumber primer diperoleh dari wawancara dengan daftar pertanyaan adalah wisatawan mancanegara dan wisatawan domestik sedangkan sumber data primer dari wawancara mendalam adalah Kepala Dinas Pariwisata, Kepala Bidang pada Dinas Pariwisata Kabupaten Badung dan pihak pengelola daya tarik wisata.

Sampel dalam penelitian ini diambil dengantekniksampling yang digunakan dengan tehnik purposive accidental sampling adalah dimana sampel ditentukan atas dasar kebetulan, artinya siapa saja yang secara kebetulan dipilih atau bersedia dipilih menjadi anggota sampel pada saat penelitian, sehinggadidapatkan jumlah sampel sebesar 156 orang pada empatdaya tarik wisata tersebut.

\section{Identifikasi Variabel}


Ada 3 (tiga) jenis variabel dipaparkan pada Tabel 1 yang akan digunakan dalam penelitian ini.

\begin{tabular}{lc} 
& $\begin{array}{c}\text { Tabel 1 } \\
\text { Identifikasi Variabel }\end{array}$ \\
\hline \multicolumn{1}{c}{ Variabel } & Klasifikasi Variabel \\
\hline Daya Tarik Wisata & Independent/exogen $\left(\mathrm{X}_{1}\right)$ \\
Kualitas Pelayanan & Independent/exogen $\left(\mathrm{X}_{2}\right)$ \\
Fasilitas & Independent/exogen $\left(\mathrm{X}_{3}\right)$ \\
Niat Kunjungan Kembali & Dependent/ endogen $\left(\mathrm{Y}_{2}\right)$ \\
Wisatawan & \\
Kepuasan Wisatawan & $\begin{array}{c}\text { Mediasi/intervening, } \\
\text { dependent/endogen, } \\
\text { independent/exogen }\left(\mathrm{Y}_{1}\right)\end{array}$ \\
\hline
\end{tabular}

Sumber: Data Penelitian, 2016

\section{Definisi Operasional Variabel}

1) Daya Tarik Wisata $\left(X_{1}\right)$ adalah persepsi wisatawan terhadap daya tarik wisata berupa atraksi wisata yang meliputi keunikan, keaslian, cuaca/iklim, keindahan serta memberikan manfaat dan nilai bagi wisatawan sehingga mampu mendorong wisatawan untuk berkunjung ke tempat tersebut.

2) Kualitas Pelayanan $\left(X_{2}\right)$ adalah pelayanan yang sesuai dengan harapan wisatawan atau melebihi harapan.

3) Fasilitas $\left(X_{3}\right)$ adalah ketersediaan fasilitas bagi wisatawan yang berkunjung sehingga dapat memberikan keamanan dan kenyamanan di daya tarik wisata tersebut

4) Kepuasan wisatawan $\left(\mathrm{Y}_{1}\right)$ merupakan kepuasan dari wisatawan yang dapat diukur dari kenyamanan fasilitas, keamanan, infrastruktur,atraksi serta suasana yang menyenangkan. 
Ni Nyoman Ayu Wiratini M., N. Djinar Setiawan, dan Ni Ny. Yuliarmi. Analisis Faktor.....

5) Niat Kunjungan Kembali Wisatawan $\left(\mathrm{Y}_{2}\right)$ adalah suatu bentuk kesetiaan wisatawan dengan melakukan kunjungan berulang di masa depan serta merekomendasikan kepada kerabat atau teman mengenai daya tarik wisata tersebut.

\section{Teknik Analisis Data}

Analisis jalur (Path analysis) merupakan perluasan dari analisis regresi linier berganda untuk menaksir hubungan kausalitas antar variabel. Dalam analisis jalur terdapat suatu variabel yang berperan ganda yaitu sebagai variabel independen pada suatu hubungan namun menjadi varibel dependen pada hubungan lain (Suyana Utama, 2015).

Pengujian hipotesis mediasi dapat dilakukan dengan prosedur uji Sobel (Sobel Test). Uji sobel dilakukan dengan cara menguji kekuatan pengaruh tidak langsung variabel independen (X) ke variabel dependen (Y) melalui variabel intervening $(\mathrm{M})$.

\section{Hasil dan Pembahasan}

\section{1) Evaluasi Terhadap Pemenuhan Analisis Jalur}

Pemeriksaan terhadap asumsi yang melandasi analisis jalur perlu dilakukan agar hasil penelitian yang dilakukan menjadi lebih memuaskan. Asumsi yang melandasi analisis jalur adalah sebagai berikut :

1) Dalam model analisis jalur hubungan antarvariabel adalah linier dan aditif. Uji linieritas menggunakan curve fit dan menerapkan prinsip parsimoni, yaitu apabila model signifikan atau non signifikan berarti dapat dikatakan model 
berbentuk linier. Berdasarkan hasil analisis untuk uji linieritas, ditunjukkan sebagai berikut.

Tabel 2

Hubungan Linier AntarVariabel Penelitian

\begin{tabular}{lccccc}
\hline $\begin{array}{l}\text { Hubungan } \\
\text { Variabel }\end{array}$ & R Square & F & df 1 & df 2 & Sig. \\
\hline X1 $\rightarrow$ Y1 & 0,488 & 147,006 & 1 & 154 & 0.000 \\
X2 $\rightarrow$ Y1 & 0,685 & 334,853 & 1 & 154 & 0.000 \\
X3 $\rightarrow$ Y1 & 0,662 & 301,258 & 1 & 154 & 0.000 \\
X1 $\rightarrow$ Y2 & 0,362 & 87,335 & 1 & 154 & 0.000 \\
X2 $\rightarrow$ Y2 & 0,407 & 105,629 & 1 & 154 & 0,000 \\
X3 $\rightarrow$ Y2 & 0,352 & 83,826 & 1 & 154 & 0.000 \\
Y1 $\rightarrow$ Y2 & 0,454 & 128,280 & 1 & 154 & 0.000 \\
\hline
\end{tabular}

Sumber : Data diolah, 2017

Tabel 2 menunjukkan semua variabel berhubungan secara linier satudengan lainnya, dengan signifikansi yang kurang dari 0,08. Besarnya koefisien korelasi dari seluruh butir pertanyaan yang terdiri dari 5 butir pertanyaan untuk variabel Daya Tarik Wisata $\left(\mathrm{X}_{1}\right), 17$ butir pertanyaan untuk variabel Kualitas Pelayanan $\left(\mathrm{X}_{2}\right), 6$ butir pertanyaan untuk variabel Fasilitas $\left(\mathrm{X}_{3}\right), 5$ butir pertanyaan untuk variabel Kepuasan Wisatawan $\left(\mathrm{Y}_{1}\right)$ dan 2 butir pertanyaan untuk variabel Niat Kunjungan Kembali Wisatawan. Menurut Arikunto (2002), koefisien validitas tiap butir soal yang diperoleh, dibandingkan dengan nilai $r$ daritabel, dimana dari hasil perhitungan koefisien korelasi $\left(\mathrm{r}_{\mathrm{xy}}\right) 35$ butir pertanyaan mempunyai $\mathrm{r}$ hitung lebih besar dari $r$ table, sehingga dapat disampaikan bahwa 35 butir pertanyaan tersebut dinyatakan layak sebagai instrumen untuk mengukur data penelitian.Sedangkan hasil uji reliabel dapat dilihat pada Tabel 3.

Tabel 3

Hasil Uji Reliabilitas

\begin{tabular}{lcc}
\hline \multicolumn{1}{c}{ Variabel } & Alpha Cronbach & Keterangan \\
\hline Daya tarik wisata $\left(\mathrm{X}_{1}\right)$ & 0,874 & Reliabel \\
Kualitas pelayanan $\left(\mathrm{X}_{2}\right)$ & 0,969 & Reliabel
\end{tabular}


Ni Nyoman Ayu Wiratini M., N. Djinar Setiawan, dan Ni Ny. Yuliarmi. Analisis Faktor.....

Dari hasil uji reabilitas diperoleh koefisien alpha sebesar 0,874 untuk variabel daya tarik wisata $\left(\mathrm{X}_{1}\right)$, sedangkan Kualitas Pelayanan $\left(\mathrm{X}_{2}\right)$ mempunyai koefisien alpha sebesar 0,969. Koefisien alpha sebesar 0,897 untuk variabel Fasilitas $\left(\mathrm{X}_{3}\right)$, sedangkan variabel Kepuasan Wisatawan $\left(\mathrm{Y}_{1}\right)$ mempunyai koefisien alpha sebesar 0,948 dan koefisien alpha sebesar 0,866 untuk variabel Niat Kunjungan Kembali Wisatawan $\left(\mathrm{Y}_{2}\right)$. Menurut Santosa (2015), variabel-variabel ini dapat dinyatakan reliabel dilihat dari nilai cronbach"s alpa> 0,6, maka variabel yang mempunyai nilai yang lebih besar dari pada 0,6 atau mendekati 1 dinyatakan reliabel. Sehingga dapat disampaikan bahwa butir-butir pertanyaan mengenai Daya Tarik Wisata, Kualitas Pelayanan, Fasilitas, Kepuasan Wisatawan dan Niat Kunjungan Kembali Wisatawan merupakan pertanyaan yang reliabel. Berdasarkan hal tersebut dapat disampaikan bahwa keseluruhan pertanyaan pada kuisioner dinyatakan reliabel atau handal dalam rangka penelitian.

\section{2) Evaluasi Terhadap Validitas Model}

Pemeriksaan validitas model, dapat dilakukan dengan melihatkoefesien determinasi total, yang hasilnya sebagai berikut:

$$
\begin{aligned}
& R_{m}^{2}=1-P_{e 1}^{2} P_{e 2}^{2} \ldots P_{e p}^{2} \\
& \mathrm{R}^{2}{ }_{\mathrm{m}}=1-\sqrt{(1-0,746)} \sqrt{(1-0,492)} \\
& \mathrm{R}^{2}{ }_{\mathrm{m}}=1-0,359 \\
& \mathrm{R}_{\mathrm{m}}{ }_{\mathrm{m}}=0,641
\end{aligned}
$$


Koefisien determinasi total diperoleh sebesar 64,1 persen atau dengan kata lain informasi yang terkandung dalam data sebesar 64,1 persen dapat dijelaskan oleh model, sedangkan sisanya yaitu 35,9 persen dijelaskan oleh variabel lain yang tidak terdapat dalam model.

3) Pengaruh Variabel Daya Tarik Wisata $\left(\mathbf{X}_{1}\right)$, Kualitas Pelayanan $\left(\mathbf{X}_{2}\right)$, Fasilitas $\left(\mathbf{X}_{3}\right)$ terhadap Kepuasan Wisatawan $\left(\mathbf{Y}_{1}\right)$

Berdasarkan hasil analisis statistik mengenai pengaruh variabel bebas $\left(\mathrm{X}_{1}, \mathrm{X}_{2}\right.$, $\mathrm{X}_{3}$ ) terhadap variabel mediasi $\left(\mathrm{Y}_{1}\right)$ dapat dilihat pengaruhnya sebagai berikut .

Tabel 4

Pengaruh Daya Tarik Wisata, Kualitas Pelayanan dan Fasilitas Terhadap Kepuasan Wisatawan

\begin{tabular}{|c|c|c|c|c|c|c|}
\hline \multirow{2}{*}{\multicolumn{2}{|c|}{ Model }} & \multicolumn{2}{|c|}{ Unstandardized Coefficients } & \multicolumn{2}{|l|}{$\begin{array}{l}\text { Standardized } \\
\text { Coefficients }\end{array}$} & \multirow[b]{2}{*}{ Sig. } \\
\hline & & B & Std. Error & Beta & $\mathrm{t}$ & \\
\hline \multirow[t]{4}{*}{1} & (Constant) & -.175 & .204 & & -.853 & .395 \\
\hline & $\mathrm{X} 1$ & .194 & .075 & .164 & 2.591 & .011 \\
\hline & $\mathrm{X} 2$ & .409 & .101 & .361 & 4.048 & .000 \\
\hline & $\mathrm{X} 3$ & .451 & .082 & .408 & 5.495 & .000 \\
\hline
\end{tabular}

a. Dependent Variable: Y1

Hasil analisis pada Tabel 4 menunjukkan bahwa Daya Tarik Wisata, Kualitas Pelayanan dan Fasilitas berpengaruh positif dan signifikan terhadap kepuasan wisatawan. Hal ini bisa dilihat dari tingkat signifikansi variabel yang kurang dari 0,08. Pengaruh positif yang diperoleh berdasarkan hasil analisis statistik menunjukkan bahwa tiap peningkatan dari daya tarik wisata, kualitas pelayanan dan fasilitas akan meningkatkan kepuasan wisatawan.

4) Pengaruh variabel Daya Tarik Wisata $\left(\mathbf{X}_{1}\right)$, Kualitas Pelayanan $\left(\mathbf{X}_{2}\right)$, Fasilitas $\left(\mathrm{X}_{3}\right)$, Kepuasan Wisatawan $\left(Y_{1}\right)$ terhadap Niat Kunjungan Kembali Wisatawan $\left(\mathbf{Y}_{2}\right)$ 
Ni Nyoman Ayu Wiratini M., N. Djinar Setiawan, dan Ni Ny. Yuliarmi. Analisis Faktor.....

Hasil analisis statistik tentang pengaruh variabel bebas $\left(\mathrm{X}_{1}, \mathrm{X}_{2}, \mathrm{X}_{3}\right)$ dan variabel mediasi $\left(\mathrm{Y}_{1}\right)$ terhadap variabel terikat $\left(\mathrm{Y}_{2}\right)$, dapat dilihat pada tabel 5.13, yakni menunjukkan Daya Tarik Wisata dan Kepuasan Wisatawan berpengaruh positif dan signifikan terhadap Niat Kunjungan Kembali Wisatawan. Hal ini bisa dilihat dari tingkat signikansi variabel yang kurang dari 0,08 . Pengaruh positif yang diperoleh berdasarkan hasil analisis statistik menunjukkan bahwa tiap peningkatan dari daya tarik wisata dan kepuasan wisatawan akan meningkatkan niat kunjungan kembali wisatawan. Sedangkan variabel kualitas pelayanan dan fasilitas berpengaruh positif dan tidak signifikan terhadap niat kunjungan kembali wisatawan, yang berarti Ho diterima karena memiliki arah pengaruh positif dan tidak signifikan dari hipotesis yang diajukan, yakni Kualitas Pelayanan berpengaruh positif dan signifikan terhadap Niat Kunjungan Kembali Wisatawan, seperti ditunjukkan pada Tabel 5.

Tabel 5

Pengaruh Daya Tarik Wisata, Kualitas Pelayanan, Fasilitas dan Kepuasan Wisatawan Terhadap Niat Kunjungan Kembali Wisatawan

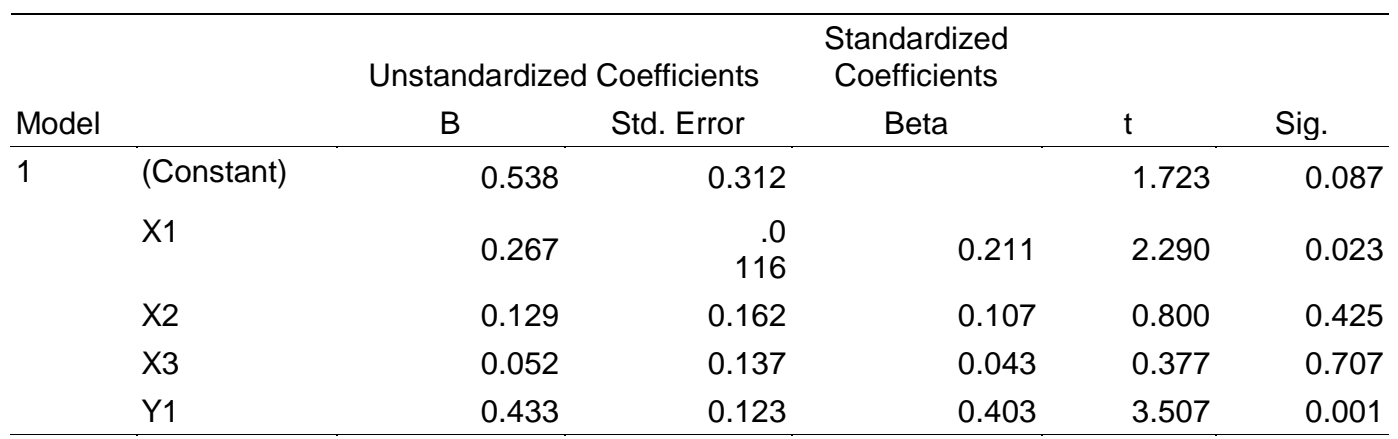

a. Dependent Variable: Y2

\section{2) Koefisien Jalur}




\section{1) Pengaruh Langsung Daya Tarik Wisata $\left(X_{1}\right)$, Kualitas Pelayanan $\left(X_{2}\right)$,}

\section{( $\left.\mathbf{X}_{3}\right)$ terhadap Kepuasan Wisatawan $\left(\mathbf{Y}_{1}\right)$ dan Niat Kunjungan}

\section{Kembali Wisatawan $\left(\mathbf{Y}_{2}\right)$}

Berdasarkan hasil olah data SPSS bahwa Daya Tarik Wisata, Kualitas

Pelayanan dan Fasilitasberpengaruh positif dan signifikan terhadap Kepuasan

Wisatawan. Daya Tarik Wisataberpengaruh positif dan signifikan terhadap Niat Kunjungan Kembali Wisatawan,Kualitas Pelayananberpengaruh positif dan tidak signifikan terhadapNiat Kunjungan Kembali Wisatawan,Fasilitasberpengaruh positif dan tidak signifikan terhadap Niat Kunjungan Kembali Wisatawan, dan Kepuasan Wisatawan berpengaruh positif dan signifikan terhadap Niat Kunjungan Kembali Wisatawan.

Tabel 6

Ringkasan Koefisien Jalur

\begin{tabular}{cccccc}
\hline Hubungan & $\begin{array}{c}\text { Koefisien } \\
\text { Regresistandar }\end{array}$ & $\begin{array}{c}\text { Standard } \\
\text { Error }\end{array}$ & t hitung & P. value & Ket \\
\hline $\mathrm{X}_{1} \rightarrow \mathrm{Y}_{1}$ & 0,194 & 0,075 & 2,591 & 0,011 & $\begin{array}{c}\text { Positif dan } \\
\text { Signifikan } \\
\mathrm{X}_{2} \rightarrow \mathrm{Y}_{1}\end{array}$ \\
$\mathrm{X}_{3} \rightarrow \mathrm{Y}_{1}$ & 0,409 & 0,101 & 4,048 & 0,000 & $\begin{array}{c}\text { Positif dan } \\
\text { Signifikan }\end{array}$ \\
$\mathrm{X}_{1} \rightarrow \mathrm{Y}_{2}$ & 0,451 & 0,082 & 5,495 & 0,000 & $\begin{array}{c}\text { Positif dan } \\
\text { Signifikan }\end{array}$ \\
$\mathrm{X}_{2} \rightarrow \mathrm{Y}_{2}$ & 0,129 & 0,116 & 2,290 & 0,023 & $\begin{array}{c}\text { Positif dan } \\
\text { Signifikan }\end{array}$ \\
$\mathrm{X}_{3} \rightarrow \mathrm{Y}_{2}$ & 0,052 & 0,162 & 0,800 & 0,425 & $\begin{array}{c}\text { Positif dan } \\
\text { Tidak Signifikan } \\
\text { Positif dan }\end{array}$ \\
$\mathrm{Y}_{1} \rightarrow \mathrm{Y}_{2}$ & 0,433 & 0,137 & 0,377 & 0,707 & $\begin{array}{c}\text { Tidak Signifikan } \\
\text { Positif dan } \\
\text { Signifikan }\end{array}$ \\
\hline
\end{tabular}

Sumber: Data diolah, 2017

Keterangan :

$\mathrm{Y}_{2} \quad$ : Niat Kunjungan Kembali Wisatawan

$\mathrm{Y}_{1} \quad$ : Kepuasan Wisatawan

$\mathrm{X}_{1} \quad$ : Daya Tarik Wisata

$\mathrm{X}_{2} \quad$ : Kualitas Pelayanan

$\mathrm{X}_{3} \quad$ : Fasilitas 
Ni Nyoman Ayu Wiratini M., N. Djinar Setiawan, dan Ni Ny. Yuliarmi. Analisis Faktor.....

Berdasarkan ringkasan koefisien jalur pada Tabel 6, maka dapat dibuat diagram jalur seperti Gambar 1 sebagai berikut:

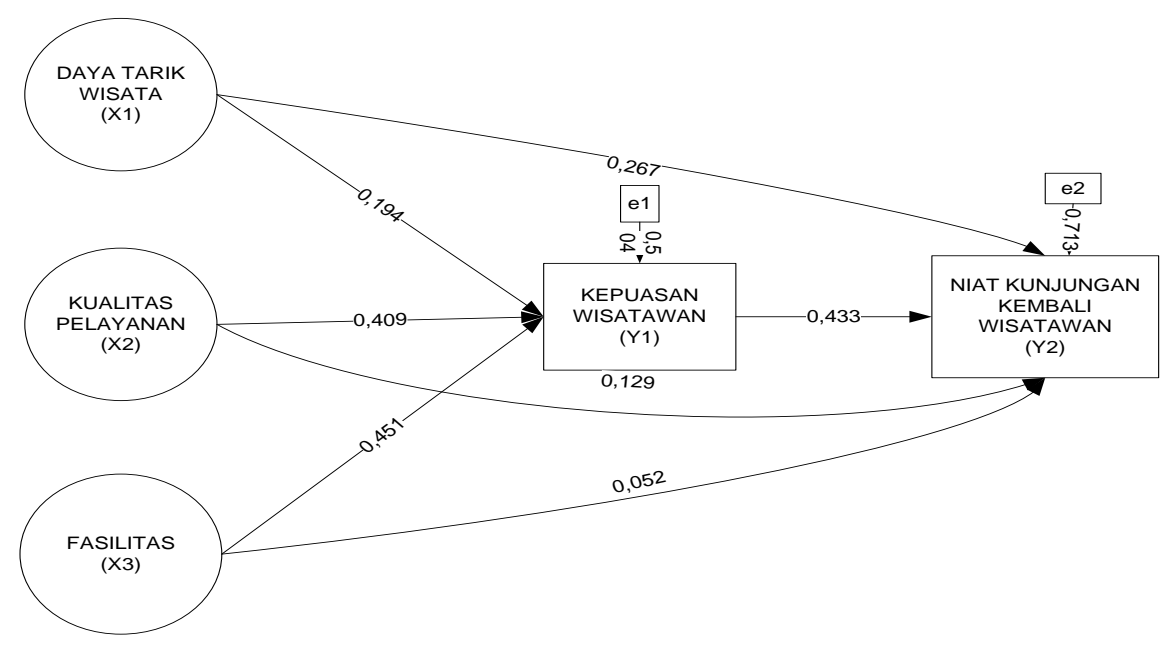

Gambar 1 Diagram Jalur Penelitian

2) Pengaruh Tidak Langsung Kepuasan Wisatawan Yang Memediasi Kualitas Daya Tarik Wisata, Faslitas, Dan Kualitas Pelayanan Terhadap Niat Kunjungan Kembali Wisatawan

Menganalisis pengaruh tidak langsung variabel penelitian melalui variabel mediasi dilakukan uji mediasi atau intervening. Hasil pengujian antaraVariabel Daya Tarik Wisata $\left(\mathrm{X}_{1}\right)$, Kualitas Pelayanan $\left(\mathrm{X}_{2}\right)$, Pelayanan $\left(\mathrm{X}_{3}\right)$ terhadap Niat Kunjungan Kembali Wisatawan $\left(\mathrm{Y}_{2}\right)$ melalui Kepuasan Wisatawan $\left(\mathrm{Y}_{1}\right)$, dapat dilihat pada Tabel 7 .

Tabel 7

Hasil Uji Variabel Intervening

\begin{tabular}{lclllll}
\hline $\begin{array}{l}\text { Variabel } \\
\text { Exogen }\end{array}$ & $\begin{array}{l}\text { Variabel } \\
\text { Mediasi }\end{array}$ & $\begin{array}{l}\text { Variabel } \\
\text { Endogen }\end{array}$ & ab & Sab & Z & Keterangan \\
\hline $\begin{array}{l}\text { Daya Tarik } \\
\text { Wisata }\end{array}$ & $\begin{array}{c}\text { Kepuasan } \\
\text { Wisatawan }\end{array}$ & $\begin{array}{l}\text { Niat Kunjungan } \\
\text { Kembali Wisatawan }\end{array}$ & 0,084 & 0,041 & 2,049 & Signifikan \\
$\begin{array}{l}\text { Kualitas } \\
\text { Pelayanan }\end{array}$ & $\begin{array}{l}\text { Kepuasan } \\
\text { Wisatawan }\end{array}$ & $\begin{array}{l}\text { Niat Kunjungan } \\
\text { Kembali Wisatawan }\end{array}$ & 0,177 & 0,067 & 2,642 & Signifikan
\end{tabular}




$\begin{array}{lllllll}\text { Fasilitas } & \text { Kepuasan } & \text { Niat Kunjungan } & 0,195 & 0,066 & 2,955 & \text { Signifikan } \\ & \text { Wisatawan } & \text { Kembali Wisatawan }\end{array}$

Sumber: Data diolah, 2017

Kriteria yang digunakan dalam analisis ini adalah $\mathrm{z}$ hitung $>\mathrm{z}$ tabel, maka $\mathrm{H}_{0}$ ditolak. Terdapat peran mediasi Kepuasan Wisatawan dalam hubungan Daya Tarik Wisata terhadap Niat Kunjungan Kembali Wisatawan dengan z hitung 2,049 $>$ 1,751.Terdapat peran mediasi Kepuasan Wisatawan dalam hubungan Kualitas Pelayanan terhadap Niat Kunjungan Kembali Wisatawan dengan z hitung 2,642>1,751. Terdapat peran mediasi Kepuasan Wisatawan dalam hubungan Fasilitas terhadap Niat Kunjungan Kembali Wisatawan dengan z hitung2,955>1,751.Variabel Kepuasaan Wisatawan berperan sebagai partial mediationpada variabel Daya Tarik Wisata, sedangkan pada variabel Kualitas Pelayanan dan Fasilitas berperan sebagai full mediation.

\section{3) Pengaruh Langsung, Tidak Langsung, dan Pengaruh Total}

Analisis pengaruh langsung, pengaruh tidak langsung dan pengaruh total dari variabel yang diteliti ditunjukan untuk mengetahui kekuatan pengaruh antar variabel, baik pengaruh langsung, tidak langsung maupun pengaruh totalnya. Berdasarkan perhitungan maka dapat diketahui besarnya pengaruh langsung dan pengaruh tidak langsung antar variabel. Pengaruh langsung dan tidak langsung serta total pengaruh Daya Tarik Wisata $\left(\mathrm{X}_{1}\right)$, Kualitas Pelayanan $\left(\mathrm{X}_{2}\right)$, Fasilitas $\left(\mathrm{X}_{3}\right)$, terhadap Kepuasan Wisatawan $\left(\mathrm{Y}_{1}\right)$ dan Niat Kunjungan Kembali Wisatawan $\left(\mathrm{Y}_{2}\right)$ ditunjukkan seperti pada Tabel 8

\section{Tabel 8}

Pengaruh Langsung dan Tidak Langsung Serta Total Pengaruh Daya Tarik Wisata $\left(\mathbf{X}_{1}\right)$, Kualitas Pelayanan $\left(\mathbf{X}_{2}\right)$, Fasilitas $\left(\mathbf{X}_{3}\right)$ terhadap Kepuasan Wisatawan $\left(\mathbf{Y}_{1}\right)$ dan Niat Kunjungan Kembali Wisatawan $\left(\mathbf{Y}_{2}\right)$ 


\section{Keterangan :}

PL : Pengaruh Langsung

PTL : Pengaruh Tidak Langsung

PT : Pengaruh Total

$\mathrm{Y}_{2} \quad$ : Niat Kunjungan Kembali Wisatawan

$\mathrm{Y}_{1} \quad$ : Kepuasan Wisatawan

$\mathrm{X}_{1} \quad$ : Daya Tarik Wisata

$\mathrm{X}_{2} \quad$ : Kualitas Pelayanan

\begin{tabular}{|c|c|c|c|c|c|c|c|c|c|c|}
\hline \multirow{2}{*}{ VARIABEL } & \multicolumn{3}{|c|}{$\mathrm{X} 1$} & \multicolumn{3}{|c|}{ X2 } & \multicolumn{3}{|c|}{ X3 } & \multirow{2}{*}{$\begin{array}{l}\text { Y1 } \\
\text { PL }\end{array}$} \\
\hline & PL & PTL & PT & PL & PTL & PT & PL & PTL & PT & \\
\hline Y1 & 0,194 & - & 0,194 & 0,409 & - & 0,409 & 0,451 & - & 0,451 & - \\
\hline Y2 & 0,267 & 0,0840 & 0,351 & 0,129 & 0,177 & 0,306 & 0,052 & 0,195 & 0,247 & 0,433 \\
\hline
\end{tabular}

Pengaruh tidak langsung yang diperoleh seperti yang ditunjukkan oleh Tabel 8 menunjukkan pengaruh positip, namun pada variabel Kualitas Pelayanan Dan Fasilitas walaupun positip, tapi tidak signifikan mempengaruhi Niat Kunjungan Kembali Wisatawan, hal ini disebabkan ada faktor lain yang mempengaruhi Niat Kunjungan Kembali Wisatawan di luar model. Salah satu faktor yang berpengaruh terhadap Niat Kunjungan Kembali Wisatawan di luar model adalah travel atau agen perjalanan yang merekomendasikan daya tarik wisata kepada para wisatawan.

\section{4) Pengaruh Daya Tarik Wisata, Kualitas Pelayanan, dan fasilitas terhadap Kepuasan Wisatawan.}

Berdasarkan hasil penelitian, diperoleh pengaruhdaya tarik wisata berpengaruh positif dan signifikan terhadap kepuasan wisatawan pada 4 obyek wisata yang dikenakan retribusi. Pada Tabel 8 dapat dilihat pengaruh langsung variabel daya tarik wisata $\left(\mathrm{X}_{1}\right)$ terhadap variabel kepuasan wisatawan adalah 0,194 dan peningkatan kepuasan wisatawan dipengaruhi oleh indikator-indikator yang mendukung variabel daya tarik wisata dalam penelitian yaitu keunikan, 
keaslian, cuaca atau iklim, manfaat yang diperoleh serta keindahan dari daya tarik wisata tersebut. Keunikan dari suatu daya tarik wisata yang tidak dapat ditemukan di tempat lain akan memberikan kepuasan kepada wisatawandan adanya kebanggan karena pernah mengunjungi obyek tersebut. Keaslian dari suatu daya tarik wisata memegang peranan yang penting, dimana wisatawan akan lebih tergugah dan merasakan suatu kepuasan dengan menikmati suatu daya tarik wisata yang masih asli, dengan udara yang segar, jauh dari kebisingan, wisatawan dapat menikmati ketenangan dari daya tarik wisata tersebut. Sedangkan kondisi cuaca atau iklim sangat mempengaruhi wisatawan yang berasal dari negara yang mempunyai perbedaan iklim. Indonesia sebagai daerah beriklim tropis dan memiliki memiliki musim penghujan dan kemarau, demikian pula kondisi iklim di Kabupaten Badung. Pada musim hujan tentunya wisatawan tidak dapat secara maksimal menikmati kunjungan di daya tarik wisata tersebut. Wisatawan yang berkunjung pada suatu daya tarik wisata akan merasakan manfaatnya baik secara langsung maupun tidak langsung. Adanya manfaat yang dirasakan tentunya akan memberikan kepuasan wisatawan terhadap daya tarik wisata tersebut. Keindahan daya tarik wisata merupakan salah satu faktor yang mendorong wisatawan yang berkunjung. Keindahan alam dan bangunanyang terdapat pada daya tarik wisata yang sesuai dengan harapan, memberikan kepuasan kepada wisatawan.

Penelitian ini sejalan dengan Nurlestari (2016), yang menyatakan bahwaDaya Tarik Wisata pada Taman Safari berpengaruh positip dan signifikan terhadap Kepuasan Wisatawan yang berkunjung. Hasil penelitian ini mendukung penelitian yang dilakukan oleh Kirom (2016), yakni dari penelitiannya diperoleh 
Ni Nyoman Ayu Wiratini M., N. Djinar Setiawan, dan Ni Ny. Yuliarmi. Analisis Faktor.....

hasil Daya Tarik Wisata berpengaruh positip dan signifikan terhadap Kepuasan Wisatawan. Tanpa adanya daya tarik wisata di suatu tempat maka kepariwisataan tidak mungkin dapat berkembang, karena daya tarik wisata mampu menarik wisatawan untuk berkunjung.

Pengaruh Kualitas Pelayanan terhadap Kepuasan Wisatawan, berdasarkan analisis yang dilakukan sebelumnya didapatkan hasil bahwa Kualitas Pelayanan berpengaruh positif dan signifikan terhadap kepuasan Wisatawan. Pengaruh langsung Variabel Kualitas Pelayanan terhadap Kepuasan Wisatawan, berdasarkan Tabel 5.16 adalah 0,409 dan indikator-indikator yang mendukung dari Kualitas Pelayanan meliputi keandalan (Reliability), daya tanggap (Responsiveness), jaminan (Assurance), empati (Empathy), dan nyata (Tangible). Keandalan (Reliability) merupakan kemampuan petugas dalam memberikan pelayanan, kecekatan dalam pelayanan serta keakuratan petugas pada loket karcis. Daya tanggap (Responsiveness) merupakan kemampuan petugas yang tanggap terhadap situasi baik di loket karcis, parkir maupun tanggap dalam memberikan bantuan bagi wisatawan. Jaminan (Assurance) meliputi kenyamanan yang dirasakan wisatawan, petugas yang bersemangat dan kepastian mendapatkan pelayanan. Empati (Empathy), merupakan kemampuan petugas untuk bersikap ramah, kejelasan memberikan informasi, merespon kebutuhan wisatawan, mendapat pelayanan yang sama dan waktu berkunjung yang memadai.Nyata (Tangible) meliputi kebersihan dan kerapian petugas, fasilitas dan pelayanan yang memadai serta kemudahan mencari lokasi daya tarik wisata.Penelitian ini sejalan dengan penelitian yang dilakukan oleh Normasari (2013) diperoleh hasil Kualitas 
Pelayananberpengaruh signifikan terhadap Kepuasan Wisatawan. Dimensi Kualitas Pelayanan yang diimplementasikan dengan baik merupakan faktor yang menentukan keberhasilan suatu daya tarik wisata karena mampu memberikan kepuasan kepada wisatawan. Kualitas Pelayanan yang diberikan melebihi harapan wisatawan akan memberikan pengaruh yang baik ke depannya. Hasil penelitian ini juga sesuai dengan penelitian yang dilakukan oleh Rosita (2016) yang menemukan bahwa variabel Kualitas Pelayanan mempunyai pengaruh positif dan signifikan terhadap variabel Kepuasan Wisatawan, karena semakin meningkatnya kualitas pelayanan yang diberikan, akan memberikan dampak pada kepuasan wisatawan yang berkunjung semakin meningkat. Berdasarkan hal tersebut perlu dilakukan peningkatan sumber daya manusia pada pengelola daya tarik wisata berupa pembinaan dan pelatihan sehingga kompetensi dalam memberikan pelayananan semakin meningkat yang menimbulkan kesan mendalam pada wisatawan sehingga masing-masing obyek daya tarik wisata dapat bersaing secara sehat.

Pengaruh Fasilitas terhadap Kepuasan Wisatawan, berdasarkan analisis yang dilakukan sebelumnya didapatkan hasil bahwa Fasilitas berpengaruh positif dan signifikan terhadap Kepuasan Wisatawan. Adapun pengaruh langsung Fasilitas terhadap Kepuasan Wisatawan dapat dilihat pada Tabel 5.16 sebesar 0,451, dan variabel Fasilitator dijelaskan dengan indikator antara lain ketersediaan loket karcis, pusat informasi parkir, toilet, tempat sampah serta toko cenderamata. Penelitian ini sejalan dengan penelitian yang dilakukan oleh Stevianus (2014), hasil penelitiannya menyatakan bahwa fasilitas wisata berpengaruh positif dan 
Ni Nyoman Ayu Wiratini M., N. Djinar Setiawan, dan Ni Ny. Yuliarmi. Analisis Faktor.....

signifikan terhadap kepuasan wisatawan. Ketersediaan fasilitas pada daya tarik wisata merupakan hal yang mutlak tersedia di daerah tujuan wisata. Hal ini disampaikan juga oleh Kotler (2009: 45) menyatakan bahwa fasilitas merupakan segala sesuatu yang sengaja disediakan oleh penyedia jasa untuk dipakai serta dinikmati oleh konsumen yang bertujuan memberikan tingkat kepuasan maksimal. Sammeng dalam Sulistiyana (2015) juga menyatakan salah satu hal yang penting untuk mengembangkan pariwisata adalah melalui fasilitas. Fasilitas wisata dapat mempengaruhi persepsi dan harapan konsumen, untuk itu perusahaan harus memperhatikan aspek ini dengan baik agar persepsi konsumen dan harapan konsumen sesuai dengan kenyataan di lapangan, sehingga mampu menciptakan kepuasan konsumen.

\section{5) Pengaruh Daya Tarik Wisata, Kualitas Pelayanan, Fasilitas dan} Kepuasan Wisatawan terhadap Niat Kunjungan Kembali Wisatawan

Berdasarkan analisis yang dilakukan sebelumnya didapatkan hasil bahwa Daya Tarik Wisata berpengaruh positif dan signifikan terhadap Niat Kunjungan Kembali Wisatawan. Berdasarkan Tabel 8, pengaruh langsung variabel Daya Tarik Wisata terhadap Niat Kunjungan Kembali Wisatawan adalah 0,267 dan hasil penelitian Basiya dan Rozak (2012), menyatakan bahwa daya tarik alam, arsitektur bangunan, budaya dan sosial berpengaruh positif terhadap niat kunjungan kembali wisatawan. Menurut Nurlestari (2016), hasil penelitiaannya menyatakan bahwa Daya Tarik Wisata mempunyai pengaruh langsung dan signifikan terhadap Niat Kunjungan Kembali Wisatawan.Daya Tarik Wisata harus dijaga keasliannya serta daya tarik yang dimiliki dapat menjadi produk unggulan yang tidak dimiliki oleh daya tarik wisata lain sehingga mampu menarik minat 
wisatawan untuk berkunjung (Suwarti, 2014). Daya tarik wisata merupakan unsur yang menentukan dalam suatu penawaran pariwisata, daya tarik yang kuat dan lain dari pada yang lain menjadikan suatu daya tarik wisata mampu memotivasi wisatawan untuk melakukan kunjungan kembali terhadap daya tarik wisata tersebut (Gromang, 2003). Dengan semakin tingginya persaingan antara daya tarik wisata yang ada serta untuk meningkatkan nilai tawar, berbagai upaya telah dilakukan oleh Pemerintah Kabupaten Badung melalui Dinas Pariwisata, yang salah satunya melakukan identifikasi terhadap kebutuhan daya tarik wisata sebelum dilakukan penataan terhadap daya tarik wisata tersebut. Dari hasil identifikasi tersebut dilakukan penataan pada daya tarik wisata berupa pembangunan gapura, penataan parkir, pembangunan toilet, serta fasilitas lain di daya tarik wisata tersebut. Dengan semakin menariknya suatu daya tarik wisata, memotivasi wisatawan untuk melakukan kunjungan kembali yang berpengaruh terhadap peningkatan jumlah kunjungan wisatawan.

Pengaruh Kualitas Pelayanan terhadap Niat Kunjungan Kembali Wisatawan berdasarkan analisis yang dilakukan sebelumnya didapatkan hasil bahwa Kualitas Pelayanan berpengaruh positip namun tidak signifikan terhadap Niat Kunjungan Kembali Wisatawan. Menurut Normasari (2013), kualitas pelayanan tidak memiliki pengaruh signifikan terhadap loyalitas pelanggan, dimana loyalitas pelanggan akan menentukan keputusan untuk melakukan pembelian secara terus menerus terhadap barang atau jasa suatu perusahaan yang dipilih. Hasil penelitian Syahadat (2006), menyatakan bahwa faktor pelayanan 
Ni Nyoman Ayu Wiratini M., N. Djinar Setiawan, dan Ni Ny. Yuliarmi. Analisis Faktor.....

mempunyai pengaruh terhadap jumlah kunjungan wisatawan namun tidak signifikan.

Pengaruh Fasilitas terhadap Niat Kunjungan Kembali Wisatawan, berdasarkan analisis yang dilakukan sebelumnya didapatkan hasil bahwa Fasilitas berpengaruh positip namun tidak signifikan terhadap Niat Kunjungan Kembali Wisatawan. Hasil penelitian ini juga sejalan dengan penelitian yang dilakukan oleh Syahadat (2005) di Taman Nasional Gede Pangrango, yang menyatakan bahwa faktor pelayanan, faktor sarana prasarana, faktor obyek dan daya tarik wisata alam dan faktor keamanan secara bersama-sama (simultan) berpengaruh terhadap jumlah kunjungan wisatawan namun tidak signifikan. Jumlah kunjungan wisatawan ke daya tarik wisata didorong karena adanya niat untuk melakukan kunjungan kembali.

Berkenaan dengan Kualitas Pelayanan dan Fasilitas yang tidak signifikan terhadap Niat Kunjungan Kembali Wisatawan dipengaruhi oleh faktor-faktor lain di luar model seperti yang disampaikan pada saat wawancara dengan Pengelola Daya Tarik Wisata Uluwatu, pada tanggal 30 Januari 2017

Kita menyadari bahwa travel mempunyai peranan yang sangat penting dalam mempromosikan dan meningkatkan jumlah kunjungan pada suatu obyek wisata. Dalam usaha meningkatkan jumlah kunjungan wisatawan ke daya tarik wisata, kita sebagai pihak pengelola mengadakan kerjasama atau kesepakatan dengan travel atau agen perjalanan, sehingga travel mengikut sertakan dalam paket wisata yang ditawarkan.

Peranan penting travel atau agen perjalanan berpengaruh terhadap perkembangan suatu daya tarik wisata. Travel mempunyai kemampuan yang harus diperhitungkan karena travel mempunyai jaringan baik di dalam negeri maupun luar negeri yang dapat mempromosikan suatu daya tarik wisata. Hal ini 
akan berpengaruh terhadap jumlah kunjungan pada suatau daya tarik wisata yang didorong karena adanya niat untuk melakukan kunjungan kembali. Selain itu adanya kesepakatan antara pihak pengelola dengan travel juga berpengaruh terhadap jumlah wisatawan yang berkunjung.Menurut Pengelola Daya Tarik Wisata, adapun pertimbangan wisatawan lebih banyak mempergunakan travel yaitu adanya jaminan perjalanan wisata yang dilakukan, adanya pemandu wisata, lebih murah, dan lebih percaya diri karena melakukan perjalanan dengan rombongan.

Hal ini dibenarkan pula oleh Pengelola Daya Tarik Wisata Taman Ayun, pada saat wawancara yang dilaksanakan pada tanggal 17 Nopember 2017.

Kami mengakui bahwa travel mempunyai peranan yang sangat penting dalam mempromosikan dan meningkatkan jumlah kunjungan pada suatu daya tarik wisata. Seperti halnya daya tarik wisata Pura Taman Ayun, kita sebagai pihak pengelola tidak perlu lagi melakukan promosi karena travel sendiri yang sudah melakukan promosi karena travel mengakui bahwa Pura Taman Ayun siap dijual. Kita menyiapkan fasilitas, menjaga kebersihan serta memberikan pelayanan. Fasilitas yang kita sediakan sperti toilet adalah gratis dan kebersihannya terjamin.

Travel yang mempromosikan daya tarik wisata Pura Taman Ayun, karena dari pihak Travel mempunyai keyakinan bahwa daya tarik wisata ini layak dijual dan pihak pengelola sendiri sudah berkomitmen memberikan pelayanan yang terbaik bagi wisatawan, walaupun diakui bahwa daya tarik wisata Pura Taman Ayun lebih diminati oleh wisatawan mancanegara. Sedangkan wisatawan domestik tidak terlalu berminat berwisata ke Pura Taman Ayun. Menurut Pengelola, hal ini disebabkan karena daya tarik wisata Pura Taman Ayun tidak memiliki atraksi wisata seperti di daya tarik wisata Uluwatu yang mampu menarik wisatawan domestik. 
Ni Nyoman Ayu Wiratini M., N. Djinar Setiawan, dan Ni Ny. Yuliarmi. Analisis Faktor.....

Sedangkan Pengelola Daya Tarik Wisata Alas Pala Sangeh, I Made

Sumohon, pada saat wawancara yang dilaksanakan pada tanggal 17 Nopember 2017.

Kami sudah melakukan penataan baik secara fisik maupun sumber daya manusianya, sehingga Alas Pala Sangeh mulai dilirik oleh wisatawan yang sebelumnya ditinggalkan karena buruknya pengelolaan daya tarik wisata ini dan kita menyadari bahwa adanya persaingan untuk daya tarik wisata yang sejenis. Tidak adanya jalur wisata setelah Alas Pala Sangeh, salah satu faktor yang mempengaruhi niat berkunjung kembali wisatawan. Pada 6 bulan terakhir kita baru tahu bahwa adanya kesalahan teknis pada google map, dimana wisatawan yang berniat berkunjung ke Alas Pala Sangeh diarahkan menuju daya tarik wisata Monkey White di Ubud. Kami sudah melakukan upaya perbaikan sehingga wisatawan yang memang berniat ke Alas Pala Sangeh dapat diarahkan ke jalur yang benar. Kami mengamati bahwa kondisi jalan yang menghubungkan Kabupaten Tabanan dengan Kabupaten Badung, sebagai jalur alternatife wisatawan yang datang dari Tabanan, kondisinya sangat memperihatinkan, sehingga adanya keengganan dari travel untuk membawa wisatawan dari Tabanan melalui jalur daya tarik wisata Alas Pala Sangeh.

Kondisi jalan yang terletak pada perbatasan antara Kabupaten Badung dan

Kabupaten Tabanan kurang mendapat perhatian dari pemerintah setempat, sehingga adanya pembiaran terhadap keadaan jalan yang rusak. Bagi Kabupaten Badung, hal ini merupakan point penting karena dengan kondisi jalan yang rusak, adanya keengganan dari pihak travel untuk melintasi rute Sangeh tersebut. Pemerintah Kabupaten Badung perlu melakukan upaya koordinasi dengan Kabupaten Tabanan tersebut terkait jalan lintas kabupaten tersebut.

Pendapat dari Pengelola Daya Tarik Wisata Uluwatu, Alas Pala Sangeh dan Taman Ayun, dibenarkan oleh Pemandu Wisata dari Travel Buana Semesta, Ni Ketut Sukarni, pada saat wawancara yang dilaksanakan pada tanggal 13 Pebruari 2017. 
Kami melihat adanya kecenderungan wisatawan domestik lebih memilih paket wisata yang disediakan oleh travel, dengan pertimbangan bahwa dengan memakai travel, wisatawan lebih dapat menikmati daya tarik wisata yang ditawarkan. Namun untuk wisatawan domestik yang memiliki waktu berkunjung ke Bali yang sangat singkat, sehingga kami mengemas paket-paket wisata yang dapat menghemat waktu dan waktunya tidak habis di jalan saja. Dengan adanya kebutuhan untuk memenuhi target paket wisata tersebut, mendorong kami lebih memilih daya tarik wisata yang berada pada satu jalur perjalanan sehingga waktu yang ada lebih dapat dimanfaatkan secara maksimal. Sedangkan daya tarik wisata yang sejenis yang ada di Kabupaten Badung dan Kabupaten lainnya,kami akan memilih daya tarik wisata yang waktu tempuhnya tidak terlalu lama. Seperti daya tarik wisata yang sejenis yaitu Taman Ayun dan Tanah Lot, tentunya kami akan lebih memilih paket Tanah Lot - Bedugul, daripada Taman Ayun.

Pihak travel atau agen perjalanan yang lebih menekankan pada pemanfaatan waktu yang tersedia, akan lebih memilih daya tarik wisata yang berada pada satu jalur serta dapat mencapai beberapa daya tarik wisata sekaligus. Hal ini perlu menjadi pertimbangan Pemerintah Kabupaten Badung, mengingat terutama Badung Tengah dan Selatan merupakan jalur yang padat, sehingga perlu dicarikan solusi mengenai kemacetan tersebut, sehingga waktu tempuh wisatawan ke daya tarik wisata tidak terlalu lamadan waktu kunjungan mereka dapat dimanfaatkan dengan sebaik-baiknya.

Berdasarkan uraian tersebut di atas, Pemerintah Daerah Kabupaten Badung mempunyai kewajiban memfasilitasi kerja sama antara pengelola daya tarik wisata dengan travel atau agen perjalanan baik di dalam negeri maupun luar negeri untuk memperkenalkan potensi yang ada di Kabupaten Badung sehingga jumlah kunjungan wisatawan dapat ditingkatkan pada daya tarik wisata tersebut. Selain itu pemerintah perlu melakukan promosi secara berkelanjutan terhadap daya tarik wisata tersebut, sehingga lebih dikenal secara luas.Pemerintah 
Ni Nyoman Ayu Wiratini M., N. Djinar Setiawan, dan Ni Ny. Yuliarmi. Analisis Faktor.....

Kabupaten Badung perlu melakukan promosi pariwisata secara berkelanjutan untuk menggugah minat wisatawan untuk berkunjung serta meningkatkan kualitas daya tarik wisata yang ada dengan tetap menjaga keaslian serta keasriannya.

Potensi wisata yang ada pada kehidupan sosial masyarakat dapat dikemas untuk dijadikan paket wisata untuk melengkapi atraksi pada daya tarik wisata tersebut seperti tari kecak, sendratari, perang ketupat serta kehidupan social masyarakat lainnya.Keunikan, keaslian dan keindahan suatu daya tarik wisata perlu tetap dijaga dan diperhatikan dengan melibatkan peran masyarakat di sekitar daya tarik wisata sehingga timbul adanya rasa memiliki. Kondisi cuaca atau iklim di luar kemampuan manusia, maka pihak pengelola perlu menyiapkan sarana dan prasarana yang menunjang sehingga wisatawan merasa nyaman berwisata. Untuk menciptakan rasa aman dan nyaman bagi wisatawan, maka kualitas pelayanan dan fasilitas agar lebih ditingkatkan sehingga mampu memberikan kenyamanan kepada wisatawan yang berkunjung.

Pengaruh Kepuasan Wisatawan terhadap Niat Kunjungan Kembali Wisatawan, berdasarkan analisis yang dilakukan sebelumnya didapatkan hasil bahwa Kepuasan Wisatawan berpengaruh positif dan signifikan terhadap Niat Kunjungan Kembali Wisatawan.Pengaruh langsung Kepuasan Wisatawan berdasarkan Tabel 8 adalah sebesar 0,433 dan hasil penelitian ini juga sejalan dengan penelitian yang dilakukan oleh Basiya (2012), bahwa kepuasan wisatawan mancanegara berpengaruh positif terhadap niat kunjungan kembali wisatawan mancanegara. Peningkatan kepuasan wisatawan mancanegara akan meningkatkanniat kunjungan kembali wisatawan mancanegara di destinasi Jawa 
Tengah. Sedangkan penelitian yang dilakukan Hanif (2016), wisatawan yang merasa puas ketika berkunjung cenderung bermaksud melakukan kunjungan kembali, baik ke daya tarik wisata yang sama atau bahkan merasa penasaran/ingin tahu dan mencari informasi terkait daya tarik wisata lainnya yang kemudian memutuskan berkunjung kembali ke daya tarik wisata tersebut. Hal yang sama juga disampaikan oleh Putra (2016), kepuasan berpengaruh signifikan terhadap niat berkunjung kembali wisatawan.Dengan terciptanya kepuasan wisatawan yang terlahir dari hasil perbandingan antara kenyataan dan harapan, maka akan mendorong wisatawan untuk melakukan kunjungan kembali. Kunjungan yang dilakukan berulang pada daya tarik wisata yang sama berarti meningkatnya jumlah wisatawan yang berkunjung yang berdampak pada peningkatan retribusi yang diperoleh. Niat Kunjungan Kembali Wisatawan dapat dilihat dari frekuensi kunjungan yang dilakukan lebih dari 1 kali pada daya tarik wisata tersebut.

\section{6) Pengaruh Daya Tarik Wisata, Kualitas Pelayanan, Fasilitas terhadap Niat Kunjungan Kembali Wisatawan Melalui Kepuasan Wisatawan}

Berdasarkan analisis yang dilakukan sebelumnya didapatkan hasil bahwa Kepuasan Wisatawan merupakan variabel yang memediasi pengaruh Daya Tarik Wisata, Kualitas Pelayanan dan Fasilitas terhadap Niat Kunjungan Kembali Wisatawan. Peran variabel Kepuasan Wisatawan ini dalam keadaan mediation ini memiliki makna bahwa Kepuasan Wisatawan memiliki peran dalam memediasi pengaruh Daya Tarik Wisata, Kualitas Pelayanan, dan Fasilitas terhadap Niat Kunjungan Kembali Wisatawan. Niat Kunjungan Kembali Wisatawan berdampak pada jumlah kunjungan pada daya tarik wisata di Kabupaten Badung. Meningkatnya jumlah kunjungan pada daya tarik wisata akan meningkatkannya 
Ni Nyoman Ayu Wiratini M., N. Djinar Setiawan, dan Ni Ny. Yuliarmi. Analisis Faktor.....

nilai retribusi yang diterima daya tarik tersebut, yang merupakan salah satu sumber PAD Kabupaten Badung. Adapun struktur PAD Kabupaten Badung dapat disampaikan pada Tabel 9.

Tabel 9

Struktur Sumber Pendapatan Asli Daerah Kabupaten Badung Tahun 2015

\begin{tabular}{llc}
\hline No. & \multicolumn{1}{c}{ Jenis } & $\begin{array}{c}\text { Distribusi } \\
\text { Persentase (\%) } \\
\text { PAD }\end{array}$ \\
\hline 1 & Pajak daerah & 86.6 \\
2 & Retribusi Daerah & 3.1 \\
3 & Hasil Perusahaan Milik Daerah dan Hasil & 4.8 \\
& Pengelolaan Kekayaan Daerah Yang Dipisahkan & 5.5 \\
\hline
\end{tabular}

Sumber: Kabupaten Badung Dalam Angka 2016 (Data diolah)

Persentase kontribusi dari masing- masing jenis sumber PAD Kabupaten Badung, terlihat bahwa Pajak Daerah memiliki kontribusi tertinggi terbesar terhadap PAD, sedangkan Retribusi Daerah kontribusinya paling rendah dibandingkan dengan sumber PAD lainnya. Walaupun secara prosentase masih rendah, namun perolehan retribusi daerah dari tahun ke tahun meningkat dan melampui dari target yang ditetapkan.

Berdasarkan hasil penelitian Belch (2009), berkaitan dengan pendapatan asli daerah dari sektor retribusi, disampaikan bahwa kedatangan para wisatawan akan meningkatkan PAD tidak hanya melalui retribusi tetapi juga secara tidak langsung meningkatkan PAD melalui Pajak Daerah. Dengan semakin meningkatnya PAD, maka daerah akan semakin mampu untuk membiaya pembangunan yang dilaksanakan. Selain meningkatnya PAD, dengan retribusi dari daya tarik wisata ini akan mampu meningkatkan kesejahteraan masyarakat di sekitar daya tarik wisata tersebut. Berdasarkan penelitian Daryanti (2013), yang 
melakukan penelitian pada daya tarik wisata Air Terjun Guruh Gemurai di Kabupaten Kuantan Sengingi, hasil penelitiannya menyebutkan bahwa melalui retribusi dari daya tarik wisata air terjun Guruh Gemurai pendapatan daerah Kabupaten Kuantan Singingi setiap tahunnya semakin meningkat. Rata-rata pertahun perkembangan retribusi daerah dan retribusi air terjun Guruh Gemurai mulai dari tahun 2007-2009 adalah sebesar 1,35 persen. Dengan adanya distribusi dari air terjun Guruh Gemurai maka Kabupaten Kuntan Singingi dapat menaikkan taraf hidup masyarakatnya yang masih berada dibawah garis kemiskinan dan melakukan pemerataan pendapatan secara menyeluruh. Hal yang sama juga disampaikan oleh Pengelola Daya Tarik Wisata Alas Pala Sangeh, I Made Sumohon, berdasarkan wawancara pada tanggal 17 Nopember 2016 :

Kami selaku Pengelola berpedoman pada Peraturan Daerah Kabupaten Daerah Tingkat II Badung Nomor 20 Tahun 1994 Tentang Pengusahaan dan Retribusi Obyek WisataRetribusi Tempat Rekreasi dan Olahraga, pada pasal 12 disebutkan bahwa Retribusi obyek wisata disetor ke kas daerah sebesar 25 persen sedangkan 75 persen dikelola oleh Pengelola Obyek Wisata. Pembagian sebesar 75 persen ini dipergunakan oleh Desa Adat selaku yang membawahi pengelolaan daya tarik wisata untuk operasional di obyek wisata serta untuk membiaya keperluan desa adat seperti membiayai upacara piodalan di desa, sehingga masyarakat yang biasanya dikenakan iuran, dengan adanya dana retribusi ini mereka tidak dikenakan iuran sehingga dapat meringankan beban masyarakat. Hal ini secara tidak langsung berkontribusi terhadap kesejahteraan masyarakat, karena pendapatan yang dulunya diperuntukan untuk upacara adat di desa dapat dipergunakan untuk memenuhi kebutuhan lainnya.

Pengelola Daya Tarik Wisata Uluwatu, Taman Ayun dan Air Terjun Nungnung juga sependapat dengan yang disampaikan oleh Pengelola Daya Tarik Wisata Alas Pala Sangeh, bahwa dengan adanya pembagian retribusi daerah yang masuk ke pengelola daya tarik wisata sebesar 75 persen, mampu memberikan kontribusi pada kesejahteraan masyarakat. Masyarakat terbantu karena tidak diberatkan 
Ni Nyoman Ayu Wiratini M., N. Djinar Setiawan, dan Ni Ny. Yuliarmi. Analisis Faktor.....

dengan iuran yang harus dikeluarkan terkait dengan upacara adat, sehingga pendapatan yang diperoleh dapat dipergunakan untuk membiayai pendidikan, kesehatan dan memenuhi kebutuhan sehari-harinya.

\section{SIMPULAN DAN SARAN}

Berdasarkan analisis data dan pembahasan dapat disimpulkan beberapa hal sebagai berikut : Daya Tarik Wisata, Kualitas Pelayanan dan berpengaruh positif dan signifikan terhadap Kepuasan Wisatawan pada daya tarik wisata yang dikenakan retribusi tempat rekreasi dan olahraga di Kabupaten Badung selama periode penelitian. Daya Tarik Wisata dan Kepuasan Wisatawan berpengaruh positif dan signifikan terhadap Niat Kunjungan Kembali Wisatawan pada daya tarik wisata yang dikenakan retribusi tempat rekreasi dan olahraga di Kabupaten Badung selama periode penelitian. Sedangkan Kualitas Pelayanan dan Fasilitas berpengaruh positif dan tidak signifikan terhadap Niat Kunjungan Kembali Wisatawan pada daya tarik wisata yang dikenakan retribusi tempat rekreasi dan olahraga di Kabupaten Badung selama periode penelitian. Kepuasan Wisatawan merupakan variabel yang memediasi pengaruh dari Daya Tarik Wisata, Kualitas Pelayanan, dan Fasilitas terhadap Niat Kunjungan Kembali Wisatawan pada daya tarik wisata yang dikenakan retribusi tempat rekreasi dan olahraga di Kabupaten Badung selama periode penelitian.

Berdasarkan hasil analisis dan kesimpulan yang diperoleh, saran-saran yang diajukan adalah: Mengingat pentingnya peranan travel dalam meningkatkan jumlah kunjungan wisatawan, maka Pemerintah Daerah Kabupaten Badung dengan menggandeng lembaga kepariwisataan di Badung dapat memfasilitasi 
antara travel dengan pengelola daya tarik wisata dengan cara mengundang travel/agen perjalanan baik di dalam negeri maupun di luar negeri untuk memperkenalkan potensi wisata yang ada di Kabupaten Badung. Promosi pariwisata dapat dilakukan dengan memanfaatkan informasi teknologi yang ada maka dapat menjangkau konsumen yang lebih luas selain adanya upaya-upaya pemeliharaan dan pelestarian daya tarik wisata, peningkatan kualitas pelayanan serta fasilitas yang ada pada masing-masing daya tarik wisata tersebut. Selain itu pelaksanaan event-event yang bertaraf nasional maupun internasional dapat dipergunakan untuk mempromosikan pariwisata di Kabupaten Badung. Pemerintah Kabupaten Badung perlu melakukan koordinasi dengan Pemerintah Kabupaten Tabanan terkait jalan lintas kabupaten, dengan akses jalan dari Tabanan ke daya tarik wisata yang ada di Badung diperbaiki, akan mendorong travel membawa wisatawan untuk berkunjung ke daya tarik wisata yang ada di Kabupaten Badung. Potensi wisata yang ada pada kehidupan masyarakat dikemas sedemikian rupa untuk dijadikan paket wisatadalam melengkapi atraksi pada daya tarik wisata tersebut seperti tari kecak, sendratari, perang ketupat serta kehidupan sosial lainnya. Keunikan, keaslian dan keindahan suatu daya tarik wisata perlu tetap dijaga dan diperhatikan dengan melibatkan peran masyarakat di sekitar daya tarik wisata sehingga mendorong masyarakat untuk ikut berperan dan tumbuhnya rasa memiliki. Kondisi cuaca atau iklim yang dapat terjadi di luar kemampuan manusia, maka pihak pengelola perlu menyiapkan sarana dan prasarana yang menunjang wisatawan sehingga merasa nyaman berwisata. 
Ni Nyoman Ayu Wiratini M., N. Djinar Setiawan, dan Ni Ny. Yuliarmi. Analisis Faktor.....

Kualitas pelayanan dan fasilitas, sebaiknya lebih ditingkatkan sehingga mampu memberikan kenyamanan kepada wisatawan yang berkunjung.

\section{REFERENSI}

Al-Ababneh, Mukhles, 2013, Service Quality And Its Impact On Tourist Satifaction, Interdisciplinary Journal Of Contempory Research In Business

Basiya, Hasan Abdul Rozak, 2012, KualitasDayaTarikWisata, Kepuasan Dan NiatKunjunganKembaliWisatawanMancanegara Di Jawa Tengah, JurnalDinamikaKepariwisataanVol.XI No. 2 Oktober 2012

Belch, G. (2009). Advertising and Promotion : An Integrated Marketing Communication Perpective, New Jersy: Pearson Education.

Daryanti, 2013, Kontribusi Objek Wisata Dalam Peningkatan Ekonomi Masyarakat Kabupaten Kuantan Singingi Menurut Perspektif Ekonomi Islam, Hukum Islam, Vol. XIII No. 1Nopember 2013

Gromang, Frans, 2003, ManajemenKepariwisataan, PT. PradnyaParamita, Jakarta

Kotler, P, Makens, JC, 2009, Marketing for Hospitality and Tourism, $4^{\text {th }}$ ed, Prentice Hall, New York

Normasari, Selvy, SrikandiKumadji, AndrianiKusumawati, 2013, JurnalAdministrasiBisnis, Volume 6, No. 2, 2 Desember 2013

Nurlestari, AjengFitri, 2016, Pengaruh Daya Tarik Wisata Terhadap Niat Kunjungan Ulang Wisatawan Dengan Kepuasan Wisatawan Sebagai Variabel Intervening Pada Taman Safari Indonesia Cisarua Bogor, JurnalPariwisata, 2016

Santoso, S. (2015). Menguasai Statistik Parametrik Konsep dan Aplikasi SPSS. Jakarta: PT Elek Media Komputindo.

Suwarti, 2014, PengaruhDayaTarikWisataTerhadapMinatKunjunganWisatawan, JurnalImiahPariwisata, Gemawisata, Volume 11, No.1, 2014

Ulusoy, Recep, 2011, The Effects of Tourism Sector on Turkish Economy, International Research Journal of Finance and Economics ISSN 1450-2887 Issue 77 (2011) (C) EuroJournals Publishing, Inc. 2011 http://www.internationalresearchjournaloffinanceandeconomics.com 